Lobna A. Shelbaya

\title{
Hypoglycemic and Hypolipidemic Effects of Chamomile Powder and Oil with High Fat High Fructose diet in rats
}

\section{Lobna A. Shelbaya}

Department of Home Economics, Faculty of Specific Education, Mansoura University, Mansoura, Egypt

\section{ABSTRACT}

he objective of this work was to study the effect of chamomile powder and

$T$ oil against high fat, high fructose diet induced-metabolic disturbances in rats. Thirty six male rats were randomly assigned into 6 groups for 6 weeks as following: Group (I): normal control rats (-ve) fed on basal diet, Group (II): received basal diet contained chamomile powder $20 \mathrm{~g} / \mathrm{kg}$ / diet, Group (III): received basal diet contained chamomile essential oil $2 \mathrm{~g} / \mathrm{kg} /$ diet, Group (IV):(+ve) control: high fat diet and high fructose drinking (HF\&HFr), Group (V): (+ve) and received chamomile powder $20 \mathrm{~g} / \mathrm{kg} / \mathrm{diet}$, Group (VI): (+ve) and received chamomile oil $2 \mathrm{ml} / \mathrm{kg} /$ diet After 6 weeks, body weight, BMI, blood glucose, serum insulin, and calculated HOMA-index, lipid profile, leptin, resistin, TNF- $\alpha$, total antioxidant capacity and total oxidant capacity were analyzed in the study male rats. Results showed high phenolic content in chamomile powder as well as estimate volatile components. chamomile powder and oil showed significant decrease in blood glucose, serum insulin, HOMA-index, leptin, resistin, TNF- $\alpha$, total oxidant capacity while increasing the total antioxidant capacity in addition to lipid profile normalization in groups that received high fructose high fat diet containing chamomile powder and oil as compared to (+ve) control. It can be concluded that consumption of chamomile powder and oil can improve the lipid profile, reduce insulin resistance, blood glucose level and inflammatory cytokines as well as it can protect the body from the oxidative stress, related to their phenolic compounds. Thus, chamomile consumption has a beneficial effect in control and management of diabetes and diabetes associated complications with no risk of hypoglycemic effect.

Key words: Hypoglycemic- Chamomile - Hypolipidmic- Inflammatory Cytokines 
Lobna A. Shelbaya

\section{INTRODUCTION}

Diabetic

is

considered as most serious diseases which that linked to hyperglycemia which occurs either when the pancreas cannot produce enough insulin, or when the body cannot effectively use the produced insulin (Ramachandran et al., 2010). Visceral obesity one of the main risks of metabolic disorders Dysregulated production of certain inflammatory cytokines that exceeding the anti-inflammatory adipose tissue-derived mediators (adipokines as adiponectin) is known to stimulate a state known as insulin resistance (Nishimura et al., 2009). Insulin and oral hypoglycemic drugs are commonly used for lowering blood glucose level in diabetics. However, they have numerous adverse effects including hypoglycemia, weight gain, and lactic acidosis as well as hepatic and renal dysfunction (Tripathi and Singh, 2000). Thus, many herbal products are commonly used as traditional medicine for diabetes treatment throughout the world (Pushparay et al., 2000).

Chamomile (Matricaria recutita $L$.) is a floury plant nat to Europe (Crevin and Philpott 1990). It was a curative herb because of its anti-inflammatory, calmed, antimicrobial, and antioxidant effect (Maschi et al., 2008). Chamomile essential oil used in products including baked goods, confections, alcoholic beverages and herbal teas. Chamomile flowers are prepared as tea (Harbourne, et al. 2009). Flavonoids are the richness phenolic composites in herbicide have susceptibility to simmer lipid peroxidation products, inhibit DNA oxidative harm, and clear reactive oxygen species (ROS) (Mladěnka et 
Hypoglycemic and Hypolipidemic Effects of Chamomile Powder and Oil against High Fat High Fructose diet in rats

Lobna A. Shelbaya

al., 2010) and (Galleano, et

al. 2010). The biological virility of chamomile because of phenolic composites as (apigenin, quercetin, patuletin, luteolin and glucosides), but principal ingredient of essential oil extracted from chamomile as $\alpha$-bisabolol (Hadaruga et al., 2009).

MATERIALS \& METHODS

A-Materials:

Chamomile powder and essential oil: were obtained from Agriculture Research Center, Giza, Egypt

Fructose: Fructose was purchased from the International Company for Scientific and Medical Supplies, Cairo, Egypt.

Chemicals: Kits for measurements of lipid profile were purchased from Diagnosticum Zrt, Budapest and those for measurements of TOC and TAC were obtained from Labor Diagnostika Nord $\mathrm{GmbH}$ and Co, Germany. Insulin, resistin, leptin and
This study was therefore undertaken to analyze the Chamomile (Matricaria recutita L.) powder and oil effects on blood glucose level, insulin sensitivity, lipid profile, antioxidant capacity and inflammatory cytokines in rats.

TNF- $\alpha$ enzyme were attended from IBL Co., Japan.

Experimental rats: thirty six weanling male SpragueDawley rats weighing 60-70 g aged 3 weeks were used. Rats were adapted for 1 week before dietary manipulation under laboratory healthy conditions.

B-Methods:

Determination of total phenolic compounds: Total phenolic compounds were determined according to the method of Waskmundzka $\boldsymbol{e t}$ al. (2007).

Identification of chamomile oil by GC-MS: The dry 
Lobna A. Shelbaya

flowers of chamomile were ground by domestic model electronic mixer. Each sample was subjected to hydrodistilation apparatus in a Clevenger type apparatus for 6 hours according to the method recommended by EPP, (1983). Oil has characteristic odor and sharp taste was obtained. The oils were dried over anhydrous sodium sulphate to remove traces of moisture and stored in refrigerator in dark at $4^{\circ} \mathrm{C}$ until use.

\section{Diets:}

Basal diet was prepared according to (Reeves et al., 1993). HF,HFr diet, consisted of basal diet containing $20 \%$ fat $(15 \%$ beef tallow $+5 \%$ corn oil) combined with fructose added in drinking water at $13 \% \mathrm{w} / \mathrm{v}$ which is similar to concentration of soft drinks (Light et al., 2009).

\section{Experimental Design:}

Male rats were

randomly assigned into six groups (6 rats) as following:

Group (I): normal rats (-ve control).

Group (II): received basal diet contained chamomile powder $20 \mathrm{~g} / \mathrm{kg} /$ diet

Group (III): received basal diet contained chamomile essential oil $2 \mathrm{ml} / \mathrm{kg} /$ diet Group (IV): high fat, high fructose-fed group ( $\mathrm{HF}, \mathrm{HFr})$ (+ve control)..

Group (V): (+ve control) and received chamomile powder $20 \mathrm{~g} / \mathrm{kg} /$ diet

Group (VI): (+ve control) and received chamomile oil $2 \mathrm{ml}$ $/ \mathrm{kg} /$ diet

Oral glucose tolerance tests: (OGTT), twelve hours prior to day 40, rats were fasted overnight and were subjected to OGTT. Fructose added in drinking water in groups 4,5 and 6 instead of water for the overnight fasting period to measure basal blood glucose concentrations from the tail vein blood The rats were given (2 g/kg b.w.) of glucose via 
Hypoglycemic and Hypolipidemic Effects of Chamomile Powder and Oil against High Fat High Fructose diet in rats

Lobna A. Shelbaya

oral gavage as a $40 \%$ solution, blood samples were collected at $0,30,60,90$, and $120 \mathrm{~min}$ after glucose administration. At the end of the period (6 weeks), rats were fasted overnight and the blood samples were collected into non-heparinized centrifuge tubes. Serum were separated and frozen at $-20{ }^{\circ} \mathrm{C}$ for biochemical analysis.

\section{Biochemical Parameters:}

Determination of serum insulin: Fasting serum insulin level was measured using the ultrasensitive rat insulin ELISA according to (Thorell and Lanner, 1973). Determination of insulin resistance by the homeostasis model assessment (HOMA-IR) calculated as the following formula: insulin $(\mu \mathrm{U} / \mathrm{mL}) \times$ glucose $(\mathrm{mg} / \mathrm{dl}) / 405$

(Matthews et al., 1985).

Determination of serum lipids: Serum TG, TC and HDL described by (Fossati and Prencipe, 1982, Allain, 1974 and Burstein et al., 1970), respectively. Serum LDL levels were calculated according to the equation of Friedwald et al. (1972).

Determination of serum resistin, tumor necrosis factor alpha (TNF- $\alpha)$ and leptin levels: Fasting serum resistin, TNF- $\alpha$ and leptin were measured by enzymelinked immunosorbent assay according to the methods that had previously described by (Thorell, 1973, Beutler et al., 1985 and Maffei et al., 1995), respectively.

Determination of antioxidant parameters: Serum total antioxidant and oxidant capacities were measured according to (Cao et al., 1993 and Flohe and Gunzler, 1984), respectively.

\section{Statistical Analysis:}

The obtained data were statistically analyzed using computerized SPSS 
(Statistic Program Sigmastat, Statistical Soft-Ware, SAS Institute, Cary, NC). Effects of different treatments were analyzed by one way ANOVA (Analysis of variance) test using Duncan's multiple range test and $\mathrm{p}<0.05$ was used to indicate significance between different groups (Snedecor and Cochran, 1967).

\section{RESULTS \& Discussion}

Polyphenolic

compounds are very important constituents in activating lipid free radical chains and preventing hydroperoxide. Data in Table (1) showed that the main phenolic acids identified in chamomile powder were Epicatechen (2022.30), Salicylic (309.5), Ellagic (174.1) and Cinnamic (110.75) with high contents, followed by Chlorogenic, Ferulic and Caffeine. It was reported that the flowers of chamomile contained flavonoids, tannins and

Lobna A. Shelbaya

terpenoids which showed different pharmacological properties (Hoberg et al., 2000 and Eugenio et al., 2012). Tannins are the most antioxidants present in the human diet and they are involved in protection against degenerative diseases and oxidative stress, gallic acid showed potent antioxidant activity by preventing lipid peroxidation (Shahrzad et al., 2001). Chamomile extracts rich in phenolic compounds as chlorogenic acid, umbelliferone, apigenin and apigenin-7-glucoside, and flavonoids as rutin or quercitrin. (Patricia et al. 2010)

Volatile components of chamomile were reported in Table (2) as $\alpha$-bisabolol (46.4), Terpinen - 4ol (22.1), $\beta$ bisabolol, Viridiflorene, Trans trans farnesol bisabolone, Cubebene, and other components

Chamomile volatile oil had components as (Camazulene 19.9\%), ( $\alpha$ - 
Lobna A. Shelbaya

bisabolol 20.9\%), (A and B bisabolol-oxides $21.6 \%$ and $1.2 \%$ ) and ( $\beta$-farnesen $3.1 \%$ ) as a major components. On the other hand, $\alpha$ - and $\beta$ caryophyllene,

caryophyllene -oxide, spathulenol, and also some monoterpenes like $\beta$ phellandrene, limonene, $\beta$ ocymene and $\gamma$-terpinen had lower concentrations.

(Costescu et al., 2008).

Volatile oils of chamomile including alphabisabolol and matricin were considered as antiinflammatory and antilipidemic. (Sakai and Misawa, 2015).

The results in Table(3) showed that, differences in feed intake and body weight gain between rats were insignificant in all groups except group IV (High fat, high fructose-fed) which showed significant reduction in feed intake (10.1g/day) in addition to significant increase in body weight gain (147g/6weeks) when compared to normal control. Tuomisto et al., (1999) explained that, high fat diet may induce anorexia in rats. Furthermore, Jurgens et al. (2015) reported that, rats reduce energy ingested from liquid than that intake from the solid diet. Saravanan and Leelavinothan (2006) reported that, chamomile enhances body weight loss due to its antihyperglycemic effect and improvement in insulin secretion and protective effect in controlling muscle wasting. The weight gain was insignificant between groups treated with chamomile; this indicates the minor effect of chamomile powder on lowering the BMI and weight gain. (Brown, 2014)

The results in Table (4) showed that blood glucose level in group IV was significantly higher $(133 \mathrm{mg} / \mathrm{dl})$ than normal control group $(91 \mathrm{mg} / \mathrm{dl})$. Diabetes mellitus is a chronic disease that associated with a higher blood glucose level in 
Lobna A. Shelbaya

people (Duncan et al., 2003). However, the blood glucose level in groups HF\&HFr and treated with chamomile powder and oil was improved to normal group this was due to the antihyperglycemic effect of chamomile powder and oil. The Serum insulin level was nearing to normal control in normal groups consumed chamomile powder and oil but group fed on HF\&HFr was significantly higher $(38 \mu \mathrm{U} / \mathrm{ml})$ than normal control group. Atsushi et al. (2008) suggested that antihyperglycemic action of chamomile extract is due to inhibition of hepatic glycogen degradation.

No significant difference in HOMA-index between groups consumed powder or oil of chamomile with normal control group. In addition, HOMA-index was significantly higher in group IV (HF\&HFr) +ve control when compared to the other groups which indicate the effect of chamomile powder and oil on increasing the insulin sensitivity. There are different approaches for quantitative determination of insulin resistance as well as beta-cell function, however, HOMA-index is found to be the most suitable mode (Wallace and Matthews, 2002).

Lipid profile analysis shown in Table.(5) revealed that group IV (HF\&HFr) had significantly the highest levels of triglycerides, total cholesterol, LDL-C and VLDL-C while had the lowest level of HDL-C which indicated the negative effect of HF\&HFr diet on the lipid profile. On the other hand, the best group was chamomile powder followed by chamomile oil which had significantly the lowest levels of triglycerides, total cholesterol and VLDL-C and had the highest level of HDLC. The results indicate the great effect of chamomile powder in control of dyslipidemia. It was reported that high fat diet can induce abnormal increases in serum 
Hypoglycemic and Hypolipidemic Effects of Chamomile Powder and Oil against High Fat High Fructose diet in rats

Lobna A. Shelbaya

concentrations

of

triglycerides, total cholesterol, low-density lipoprotein cholesterol and lipid peroxidation, in addition to depressed antioxidant defense system (Yan et al., 2006). Dyslipidemia caused in male rats fed on high fat and high fructose diet consumption compared to control (Amin et al., 2016).

Fructose caused troubles in metabolism due to an increment in free fatty acids and triglycerides into tissues as (liver, pancreas and muscle). Stanhope et al., (2009) Mang et al., (2016) reported that, chamomile had hypoglycemic and hypolipidemic effects on diabetic animals.

High fat\& high fructose group had high significant levels of Leptin, resistin, $\mathrm{TNF}-\alpha$ and total oxidant capacity while had the lowest total antioxidant capacity compared to the other groups. Although, leptin, resistin and $\mathrm{TNF}-\alpha$ levels in all groups were the best in chamomile powder followed by chamomile oil groups compared to normal control, These results confirm with Vincent et al., (2009) who reported that, the antioxidant effect of chamomile may be to positive effect of antioxidants on HOMAindex has been shown in healthy people. Abnormal production of inflammatory cytokines is such as TNF- $\alpha$ and IL-6 known to induce insulin resistance

(Nishimura et al., 2009). Controlling diabetes and insulin resistance can be achieved via modulation of inflammatory cytokines and adipokines (Zhang and Gao, 2016). Free radicles generation cause exhaustion in the endogenous antioxidants and can cause hepatic inflammation by activation of the inflammatory cytokines (Weisberg et al., 2008).

Leptin is a peptide hormone as an adipokine that 
Hypoglycemic and Hypolipidemic Effects of Chamomile Powder and Oil against High Fat High Fructose diet in rats

Lobna A. Shelbaya

regulate energy intake and expenditure (Brennan and Mantzoros, 2006). Leptin could inhibit the development of obesity via stimulation of the satiety centers in brain (DePaoli, 2014). Leptin is synthesized primarily in the adipocytes and its level is proportional to total body fat (Fischer et al., 2002). Most of obese peoples have deficiency in leptin receptors, which lead to leptin resistance (Tartaglia et al., 1995). Several investigations have shown that high leptin level is associated with increased risk of developing diabetes (Tong et al., 2005). TNF- $\alpha$ is an adipocytokine that involved in systemic inflammation (Moller, 2000) and is secreted by macrophages and variety of cells including adipocytes (Gimeno and Klaman, 2005). TNF- $\alpha$ inhibits insulin transduction and affect on glucose metabolism (Zou and Shao, 2008).

Chamomile produced a significant protection against oxidative stress, it decreased malondialdehyde (MDA) level and increased antioxidant enzymes as superoxide dismutase (SOD), catalase (CAT) and glutathione peroxidase (GPx). (Hichem et al., 2014)

\section{CONCLUSION}

Chamomile powder and oil have inhibitory effects on inflammatory cytokines such as TNF- $\alpha$, and leptin in addition to resistin level. It also can improve the lipid profile, insulin sensitivity, hyperglycemia control and the total antioxidant capacity with relieving of the oxidative stress.

\section{REFERENCES}

Allain CC (1974):

Quantitative-enzymatic colorimetric 
Hypoglycemic and Hypolipidemic Effects of Chamomile Powder and Oil against High Fat High Fructose diet in rats

Lobna A. Shelbaya

determination of total and HDL cholesterol in serum or plasma. Clin. Chem., 20: 470.

\section{Amin KA; Kamel HH and}

Abd Eltawab MA (2011):

The relation of high fat diet, metabolic disturbances and brain oxidative dysfunction: Brennan AM and Mantzoros CS (2006):

Drug Insight: the role of leptin in human physiology and pathophysiology emerging clinical applications. Nat. Clin. Pract. Endocrinol. Metab. 2: 318-327.

modulation by hydroxy citric acid. Lipids in Health and Disease, 10:74-85.

Atsushi K; Yuka M; JO Y; Brown D (2014): Chamomile clinical monograph. Quarterly Review of Natural Medicine 94:111-121.

Isao $A$ and Allson $A$ (2008):

Protective Effects of

Dietary Chamomile Tea on Diabetic

Complications, J. Agric. Food Chem. 56, 82068211 .

Burstein M; scholnick HR and Morfin R (1970): Rapid method for isolation of lipoproteins from human serum by precipitation with polyanions. Lipid Res., 11: 583-595.

\section{Beutler B; Greenwald D} and Hulmes JD (1985):

Identity of tumor necrosis factor and the macrophage- secreted factor cachectin. Cao, G.; Alessio, H. and Cutler, R. (1993): Oxygen - radical absorbance capacity assay for antioxidants.

Nature, 316:552-554. 
Hypoglycemic and Hypolipidemic Effects of Chamomile Powder and Oil against High Fat High Fructose diet in rats

Lobna A. Shelbaya

Free Radic. Biol. Med., 14:303-311.

Costescu CI; Hadaruga NG; Rivis A; Hadaruga DI and Lupea $A$ (2008):

Antioxidant activity evaluation of some Matricaria chamomilla L. extracts. Journal of Agroalimentary

Processes and Technologies. 14: 417432.

Crevin JK and Philpott J (1990):

Herbal medicine past and present. Vol. II Duke University Press.

DePaoli A (2014):

Leptin in common obesity and associated disorders of metabolism. $J$. Endocrinol. 223: T7181 .

Duncan BB; Schmidt MI; Pankow JS; Ballantyne CM; Couper D; Vigo A;
Hoogeveen R; Folsom AR and Heiss G (2003):

Low grade systemic inflammation and the development of type 2 diabetes: the atherosclerosis risk in communities study. Diabetes 52: 17991805.

Eugenio JG; Tatiane LO; Severino MA; Alessandra R; Alessandro L and Rosa HMG (2012):

Antioxidant Activity by DPPH Assay of Potential Solutions to be Applied on Bleached Teeth. Braz Dent J; 23(1): 22-27.

European pharmacopeia procedure (1983):

Maissoneuve, S. A.; Sainte Ruffine. Part 1, p 4.5.8.

Fischer S; Hanefeld M; Haffner SM; Fusch C; Schwanebeck U; Kohler $C$; Fucker $\mathrm{K}$ and Julius $\mathrm{U}$ (2002): 
Hypoglycemic and Hypolipidemic Effects of Chamomile Powder and Oil against High Fat High Fructose diet in rats

Lobna A. Shelbaya

Insulin-resistant

patients with type 2

diabetes mellitus have

higher serum leptin

levels independently of body fat mass. Acta.

Diabetol. 39: 105-110.

Flohe L and Gunzler WA (1984):

Oxygen radicals in biological systems. Methods Enzymol., 105: 114-212.

Fossati $P$ and Prencipe $L$ (1982):

Serum triglycerides determined

colorimetrically with an enzyme that produces hydrogen peroxide. Clin. Chem., 28: 2077-2080.

Friedewald WT; Levy RI and Frerickson DS (1972):

Estimation of the concentration of lowdensity lipoprotein cholesterol in plasma without use of the preparative ultracentrifuge. Clin.

Chem., 18: 499-502.

Galleano M; Verstraeten SV; Oteiza PI and Fraga CG (2010):

Antioxidant actions of flavonoids:

thermodynamic and kinetic analysis. Archives of Biochemistry and Biophysics, 501, 2330.

Gimeno RE and Klaman LD (2005):

Adipose tissue as an active endocrine organ: recent advances. Curr. Opin. Pharmacol. 5: 122-128.

Hadaruga NG; Hadaruga DI; Tatu C; Gruia A and Costescu C (2009):

Multivariate analysis (PCA) in Compositae biocompounds class. $J$. of Agroalimentary Processes and Technologies. 15: 201210. 
Hypoglycemic and Hypolipidemic Effects of Chamomile Powder and Oil against High Fat High Fructose diet in rats

Lobna A. Shelbaya

\begin{tabular}{crrr}
\hline Harbourne N; Jacquier J & Jurgens H; Haass W; \\
and O'Riordan D (2009): & Castaneda & TR; \\
Optimisation of the & Schurmann A; Koebnick \\
extraction & and & C and Tschöp MH (2015): \\
processing conditions of & Consuming & fructose- \\
chamomile (Matricaria & sweetened beverages \\
chamomilla L.) for & increases & body \\
incorporation into a & adiposity in mice. Obes. \\
beverage. & Food & Res., 13:1146-1156.
\end{tabular}

Chemistry, 115, 15-19.

HichemS ; Mohamed A; Jabriab A and Soulib K (2014):

Antidiarrheal and antioxidant activities of chamomile (Matricaria recutita $L$.) decoction extract in rats, $J$. of Ethnopharmacology, 152, 2, 327-332.

Hoberg E; Meier B and Sticher O (2000):

Quantitative high performance liquid chromatographic analysis of diterpenoids in Agni-casti Fructose. Planta Med 66: 352355.
Light HR; Tsanzi E; Gigliotti J; Morgan $\mathrm{K}$ and Tou JC (2009):

The Type of Caloric Sweetener Added to Water Influences Weight Gain, Fat Mass, and Reproduction in Growing SpragueDawley Female Rats. Exp. Biol. Med., 234: 651-666.

Maffei M; Burghen GA; Li H; Hudson MM and Kun LE (1995):

Leptin levels in human and rodent: measurement of plasma leptin and ob RNA and weightreduced subjects. 
Hypoglycemic and Hypolipidemic Effects of Chamomile Powder and Oil against High Fat High Fructose diet in rats

Lobna A. Shelbaya

Nature Med., 1:11551161.

Mang B; Wolters M; Schmitt B; Kelb K; Lichtinghagen R; Stichtenoth DO and Hahn A (2006):

Effects of a chamomile extract on plasma glucose, $\mathrm{Hb} \mathrm{A}$, and serum lipids in diabetes mellitus type 2. Eur. J. Clin. Invest., 36:340344.

Matthews DR; Hosker JP; Rudenski AS; Naylor BA; Treacher DF and Turner RC (1985):

Homeostasis model assessment: insulin resistance and beta-cell function from fasting plasma glucose and insulin concentrations in man. Diabetologia, 28: 412-9.

Maschi O; Dal Cero E; Galli G V; Caruso D; Bosisio $E$ and Dell' Agli $M$ (2008):
Inhibition of human

cAMP

Phosphodiesterase as a mechanism of the spasmolytic effect of Matricaria recutita L. Journal of Agricultural and Food Chemistry, 56, 5015-5020.

Mladěnka

P;

Zatloukalová L; Filipský $T$ and Hrdina R (2010):

Cardiovascular effects of flavonoids are not caused only by direct antioxidant activity. Free Radical Biology \& Medicine, 49, 963-975.

Moller DE (2000): Potential role of TNFalpha in the pathogenesis of insulin resistance and type 2 diabetes. Trends. Endocrinol. Metab. 11: 212-217.

Nishimura S; Manabe I and Nagai R (2009):

Adipose tissue inflammation in 
Hypoglycemic and Hypolipidemic Effects of Chamomile Powder and Oil against High Fat High Fructose diet in rats

Lobna A. Shelbaya

obesity and metabolic syndrome. Discov. Med. 8: 55-60.

Patricia M; Tiago $G$ and Petr S (2010):

Development and application of UHPLCMS/MS method for the determination of phenolic compounds in Chamomile flowers and Chamomile tea extracts, $82,4,1271-1280$.

\section{Pushparay P; Tan CH and} Tan BK (2000):

Effect of Averrhoea bilimbi leaf extract on blood glucose and lipid in STZ-diabetic rats. $J$. Ethanopharmacol. 72 : 69-76.

Ramachandran A; Ma RC and Snehalatha C (2010):

Diabetes in Asia.

Lancet. $375(9712)$ : 408-418.

\section{Reeves PG; Nielsen FH} and Fahey GCJr (1993):
AIN-93 purified diets for laboratory rodents: final report of the American Institute of Nutrition ad hoc writing committee on the reformulation of the AIN 76A rodent diet. J. Nutr., 123:1939-1951.

Sakai $H$ and Misawa M (2015):

Effect of sodium azulene sulfonate on capsaicin-induced pharyngitis in rats. Basic Clin Pharmacol Toxicol; 96:54-55.

Saravanan G and Leelavinothan P (2006):

Effects of Syzygium Cumini Bark on Blood Glucose, Plasma Insulin and C-peptide in Streptozotocin induced Diabetic rats. Int. $J$ Endocrinol Metab. 4: 96-105 
Hypoglycemic and Hypolipidemic Effects of Chamomile Powder and Oil against High Fat High Fructose diet in rats

Lobna A. Shelbaya

Shahrzad S; Aoyagi K; Winter A; Koyama A and Bitsch I (2001):

Pharmacokinetics of gallic acid and its relative bioavility from tea in healthy humans. J. Nut. 22: 1207-1210.

Snedecor GW and Cochran WG (1967):

Statistical Methods. 7th Ed., The Lowa State University Press., Ames, Lowa, U.S.A.

Stanhope KL; Schwarz JM; Keim NL; Griffen SC; Bremer AA and Zhang W (2009):

Consuming fructosesweetened, not glucoseadiposity and lipids and decreases insulin sensitivity in overweight/obese

humans.

J. Clin. Invest., 119:1322-1334.

Tartaglia LA; Dembski $\mathrm{M}$; Weng $\mathrm{X}$; Deng $\mathrm{N}$; Culpepper J; Devos R; Richards GJ; Campfield
LA; Clark FT; Deeds J; Muir C; Sanker S; Moriarty A; Moore KJ; Smutko JS; Mays GG; Wool EA; Monroe CA and Tepper RI (1995):

Identification and expression cloning of a leptin receptor, $O B-R$. Cell 83: 1263-1271.

Thorell JI and Lanner A (1973):

Influence of heparinplasma, EDTA-plasma and serum on the determination of insulin with three different radioimmunoassay.

Scand. J. Clin Lab. Invest., 31:187-190.

Thorell JI (1973):

A cysteine-rich adipose tissue-specific secretory factors inhibits adipocyte differentiation. Scand. J. Lab. Invest., 31:187.

Tong J; Fujimoto WY; Kahn SE; Weigle DS; McNeely MJ; Leonetti DL; 
Hypoglycemic and Hypolipidemic Effects of Chamomile Powder and Oil against High Fat High Fructose diet in rats

Lobna A. Shelbaya

Shofer JB and Boyko EJ (2005):

Insulin, C-peptide, and leptin concentrations predict increased visceral adiposity at 5and 10-year follow-ups in nondiabetic Japanese Americans. Diabetes, 54: 985-990.

\section{Tripathi SM and Singh}

DK (2000):

Molluscicidal activity of Punica granatum bark and Canna indica root. Brazilian Journal of Medical Biology Research 33:13511355.

Tuomisto, J.T.;

Pohjanvirta, R.; Unkila, M. and Tuomisto, J. (1999):

Effects of diet-induced obesity and nutrition. Pharmacol. Biochem. Beha., 62: 735-42.

Vincent HK; Bourguignon CM; Weltman AL; Vincent KR; Barrett E;
Innes KE and Taylor AG (2009):

Effects of antioxidant supplementation on insulin sensitivity, endothelial adhesion molecules, and oxidative stress in normal-weight and overweight young adults. Metabolism, 58: 254-262.

\section{Wallace TM and} Matthews DR (2002):

The assessment of insulin resistance in man. Diabet. Med. 19: 527-534.

\section{Waskmundzka}

Wianowska D; Szewczyk $K$ and Oniszczuk A (2007):

Effect of sample preparation methods on the HPLC quantitation of some phenolic acids in plant materials. Acta Chromatographica (19): 227-237.

Weisberg PS; Leibel R and Tortoriello VD (2008): 
Hypoglycemic and Hypolipidemic Effects of Chamomile Powder and Oil against High Fat High Fructose diet in rats

Lobna A. Shelbaya

Dietary curcumin

significantly improves

obesity-associated

inflammation

and

diabetes in mouse

models of diabesity, Endocrinology. 149 (7):

3549-5.

Yan MX; Yan-Qing L;

Min M; Hong-Bo $R$ and Yi K (2006):

Long-term high-fat diet induces pancreatic injuries via pancreatic microcirculatory disturbances and oxidative stress in rats with hyperlipidemia. Biochem. Biophys. Res. Comm 347(1): 192.
Zhang JQ and Gao BW (2016):

Critical role of FoxO1 in granulosa cell apoptosis caused by oxidative stress and protective effects of grape seed procyanidin B2. Oxid. Med. Cell. Longev. 16.

\section{Zou CH and Shao JH} (2008):

Role of adipocytokines in obesity-associated insulin resistance. $J$. Nutr. Biochem. 19:277286. 
Table (1): Phenolic compounds of chamomile powder (ppm)

\begin{tabular}{|c|c|}
\hline $\begin{array}{c}\text { Phenolic compounds of } \\
\text { chamomile }\end{array}$ & Ppm \\
\hline Gallic & 22.02 \\
\hline Syring & 36.60 \\
\hline 4-Amino-benzoic & 5.89 \\
\hline Epicatechen & 2022.30 \\
\hline Chlorogenic & 89.91 \\
\hline Catechein & 27.56 \\
\hline Caffeine & 78.40 \\
\hline Vanillic & 28.53 \\
\hline Ferulic & 82.74 \\
\hline Ellagic & 174.10 \\
\hline Salicylic & 309.50 \\
\hline Cinnamic & 110.75 \\
\hline
\end{tabular}


Table (2): Volatile components of chamomile essential oil

\begin{tabular}{|c|c|c|}
\hline Peak No. & Compounds & Area \% \\
\hline 1 & $\alpha$ - pinene & 1.4 \\
\hline 2 & Sabinene & 0.3 \\
\hline 3 & $\beta$-pinene & 0.1 \\
\hline 4 & $\alpha$-phellandrene & 0.4 \\
\hline 5 & $\alpha$ - terpinene & 0.1 \\
\hline 6 & T- terpinene & 0.3 \\
\hline 7 & Terpinen- 4 ol & 22.1 \\
\hline 8 & Methyl acetate & 0.3 \\
\hline 9 & $\alpha$ - cubebene & 1.9 \\
\hline 10 & Cis- $\beta$ - farnesene & 0.3 \\
\hline 11 & $\beta$ - bisabolone & 2.1 \\
\hline 12 & Trans - nerolidol & 1.0 \\
\hline 13 & Spathulenol & 0.5 \\
\hline 14 & Caryophyllene oxide & 1.2 \\
\hline 15 & Viridiflorene & 6.6 \\
\hline 16 & $\beta$ - bisabolol & 7.3 \\
\hline 17 & $\alpha$ - bisabolol oxide $\mathrm{A}$ & 1.4 \\
\hline 18 & $\alpha$ - bisabolol & 46.4 \\
\hline 19 & Chamazulene & 0.3 \\
\hline 20 & Trans-trans- farnesol & 6.1 \\
\hline 21 & Guaiazulene & 0.6 \\
\hline
\end{tabular}


Table (3): Effect of chamomile powder and oil on feed intake and body weight gain in male rats fed on basal or high fat high fructose diets

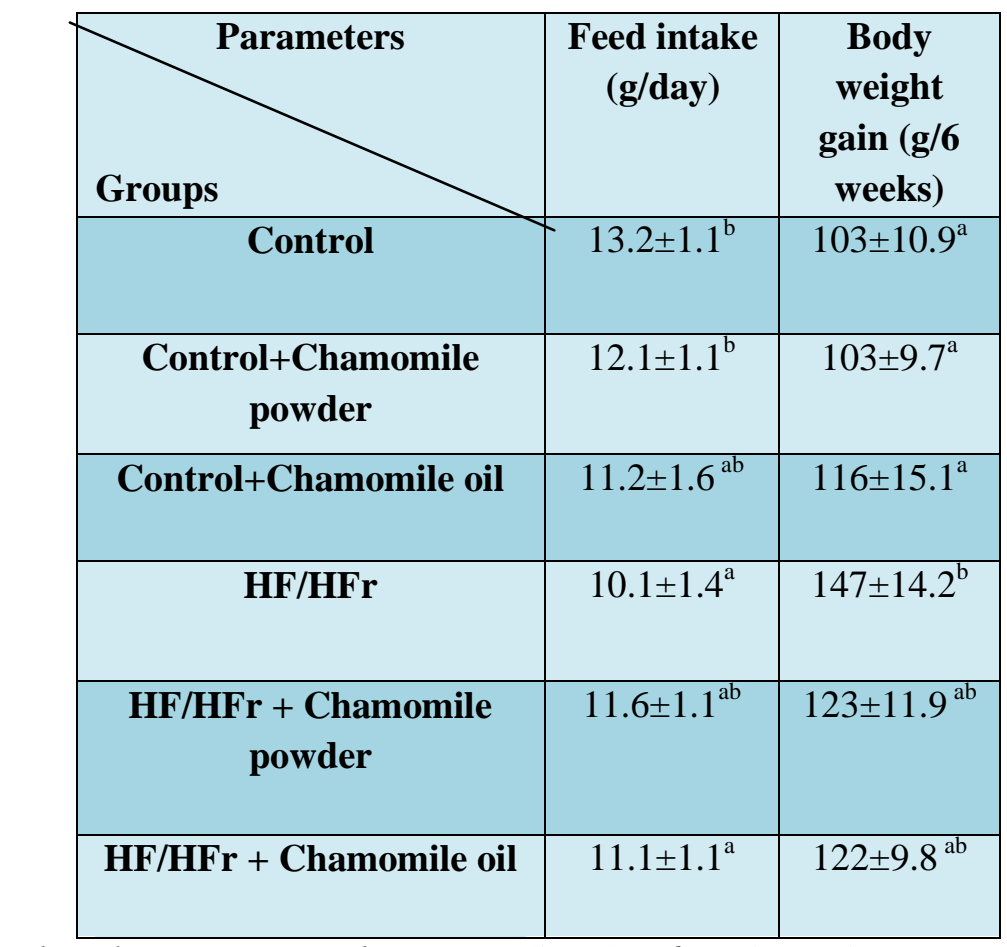

The values are expressed as mean $\pm S E M$ ( $n=6$ rats/ group).

Values with the same letters indicate insignificant difference and vice versa. 
Table (4): Effect of chamomile powder and oil on serum insulin and HOMA-index in male rats fed on basal or high fat high fructose diets

\begin{tabular}{|c|c|c|c|}
\hline Parameters & $\begin{array}{c}\text { Blood } \\
\text { Glucose } \\
(\mathbf{m g} / \mathbf{d l})\end{array}$ & $\begin{array}{c}\text { Serum } \\
\text { Insulin } \\
(\boldsymbol{\mu} \mathbf{U} / \mathbf{m l})\end{array}$ & $\begin{array}{c}\text { HOMA- } \\
\text { index }\end{array}$ \\
\hline Control & $91 \pm 11.09^{\mathrm{a}}$ & $27 \pm 0.69^{\mathrm{b}}$ & $6.05 \pm 0.85^{\mathrm{a}}$ \\
\hline $\begin{array}{c}\text { Control+Chamomile } \\
\text { powder }\end{array}$ & $90 \pm 5.04^{\mathrm{a}}$ & $28 \pm 0.97^{\mathrm{b}}$ & $6.2 \pm 0.35^{\mathrm{a}}$ \\
\hline $\begin{array}{c}\text { Control+Chamomile oil } \\
\text { HF/HFr }\end{array}$ & $111 \pm 3.3^{\mathrm{b}}$ & $23 \pm 2.1^{\mathrm{a}}$ & $6.4 \pm 0.61^{\mathrm{a}}$ \\
\hline $\begin{array}{c}133 \pm 4.9^{\mathrm{cd}} \\
\text { powder }\end{array}$ & $113 \pm 3.3^{\mathrm{b}}$ & $23 \pm 2.1^{\mathrm{a}}$ & $6.4 \pm 0.61^{\mathrm{a}}$ \\
\hline $\begin{array}{c}\text { HF/HFr + Chamomile oil } \\
\text { Chr + Chamomile }\end{array}$ & $115 \pm 2.9^{\mathrm{b}}$ & $23 \pm 2.9^{\mathrm{a}}$ & $6.5 \pm 0.63^{\mathrm{a}}$ \\
\hline
\end{tabular}

The values are expressed as mean \pm SEM ( $n=6$ rats/ group).

Values with the same letters indicate insignificant difference and vice versa. 
Table (5): Effect of chamomile powder and oil on serum lipid profile in male rats fed on basal or high fat high fructose diets

\begin{tabular}{|c|c|c|c|c|c|}
\hline Parameters & $\begin{array}{c}\text { Triglycerid } \\
\text { es (mg/dl) }\end{array}$ & $\begin{array}{c}\text { Total } \\
\text { Cholester } \\
\text { ol (mg/dl) }\end{array}$ & $\begin{array}{c}\text { HDL- } \\
\text { Cholester } \\
\text { ol (mg/dl) }\end{array}$ & $\begin{array}{c}\text { LDL- } \\
\text { Cholester } \\
\text { ol (mg/dl) }\end{array}$ & $\begin{array}{c}\text { VLDL- } \\
\text { Cholester } \\
\text { ol (mg/dl) }\end{array}$ \\
\hline Control & $76.7 \pm$ & $82.8 \pm$ & $15.9 \pm$ & $49.1 \pm$ & $15.1 \pm$ \\
$0.99^{\mathrm{ab}}$ & $0.5^{\mathrm{b}}$ & $0.16^{\mathrm{b}}$ & $0.6^{\mathrm{bc}}$ & $1.01^{\mathrm{bc}}$ \\
\hline $\begin{array}{c}\text { Control+Ch } \\
\text { amomile }\end{array}$ & $71.9 \pm$ & $72.1 \pm$ & $15.8 \pm$ & $40.5 \pm$ & $14.3 \pm$ \\
powder & $0.91^{\mathrm{a}}$ & $0.53^{\mathrm{a}}$ & $0.09^{\mathrm{b}}$ & $0.62^{\mathrm{a}}$ & $0.35^{\mathrm{ab}}$ \\
\hline Control+Ch & $77.7 \pm$ & $81.6 \pm$ & $15.7 \pm$ & $49.6 \pm$ & $15.5 \pm$ \\
amomile oil & $0.91^{\mathrm{ab}}$ & $0.46^{\mathrm{b}}$ & $0.24^{\mathrm{b}}$ & $0.46^{\mathrm{ab}}$ & $0.29^{\mathrm{bc}}$ \\
\hline HF/HFr & $88.1 \pm$ & $91.4 \pm$ & $13.3 \pm$ & $57.2 \pm$ & $17.7 \pm$ \\
& $1.09^{\mathrm{c}}$ & $0.92^{\mathrm{c}}$ & $0.15^{\mathrm{a}}$ & $1.01^{\mathrm{d}}$ & $0.41^{\mathrm{d}}$ \\
\hline HF/HFr + & $68.5 \pm$ & $78.1 \pm$ & $14.8 \pm$ & $49.1 \pm$ & $13.7 \pm$ \\
Chamomile & $0.89^{\mathrm{a}}$ & $0.43^{\mathrm{ab}}$ & $0.19^{\mathrm{ab}}$ & $1.09^{\mathrm{bc}}$ & $0.72^{\mathrm{a}}$ \\
powder & & & & & \\
\hline HF/HFr + & $76.9 \pm$ & $80.1 \pm$ & $14.5 \pm$ & $52.3 \pm$ & $15.6 \pm$ \\
Chamomile & $1.13^{\mathrm{b}}$ & $0.611^{\mathrm{ab}}$ & $0.25^{\mathrm{a}}$ & $0.68^{\mathrm{cd}}$ & $0.49^{\mathrm{bc}}$ \\
oil & & & & & \\
\hline & & & & & \\
\hline
\end{tabular}

The values are expressed as mean \pm SEM ( $n=6$ rats/ group).

Values with the same letters indicate insignificant difference and vice versa. 
Table (6): Effect of Chamomile powder and oil on serum Leptin, Resistin, TNF- $\alpha$, Total antioxidant capacity and Total oxidant capacity in male rats

\begin{tabular}{|c|c|c|c|c|c|}
\hline Parameters & $\begin{array}{l}\text { Leptin } \\
(\mathrm{pg} / \mathrm{ml})\end{array}$ & $\begin{array}{r}\text { Resistin } \\
(\mathrm{ng} / \mathrm{ml})\end{array}$ & $\begin{array}{l}\text { TNF- } \alpha \\
(\mathrm{pg} / \mathrm{ml})\end{array}$ & $\begin{array}{c}\text { Total } \\
\text { antioxida } \\
\text { nt } \\
\text { capacity } \\
\text { (mmol/L) }\end{array}$ & $\begin{array}{c}\text { Total } \\
\text { oxidant } \\
\text { capacity } \\
(\mathrm{mmol} / \mathrm{L})\end{array}$ \\
\hline Control & $\begin{array}{c}2.73 \pm \\
0.1^{\mathrm{a}}\end{array}$ & $\begin{array}{l}3.75 \pm \\
0.04^{\mathrm{ab}}\end{array}$ & $\begin{array}{l}3.8 \pm \\
0.11^{\mathrm{a}}\end{array}$ & $\begin{array}{l}1.76 \pm \\
0.04^{c}\end{array}$ & $\begin{array}{l}0.236 \pm \\
0.012^{\mathrm{a}}\end{array}$ \\
\hline $\begin{array}{l}\text { Control+Cha } \\
\text { momile } \\
\text { powder }\end{array}$ & $\begin{array}{l}2.98 \pm \\
0.31^{\mathrm{ab}}\end{array}$ & $\begin{array}{l}3.71 \pm \\
0.06^{\mathrm{ab}}\end{array}$ & $\begin{array}{l}3.73 \pm \\
0.17^{\mathrm{a}}\end{array}$ & $\begin{array}{l}1.78 \pm \\
0.06^{\mathrm{c}}\end{array}$ & $\begin{array}{c}0.235 \pm \\
0.01^{\mathrm{a}}\end{array}$ \\
\hline $\begin{array}{c}\text { Control+Cha } \\
\text { momile oil }\end{array}$ & $\begin{array}{c}3.55 \pm \\
0.131^{\mathrm{bc}}\end{array}$ & $\begin{array}{l}4.18 \pm \\
0.047^{\mathrm{bc}}\end{array}$ & $\begin{array}{l}3.8 \pm \\
0.16^{\mathrm{a}}\end{array}$ & $\begin{array}{l}1.73 \pm \\
0.07^{\mathrm{c}}\end{array}$ & $\begin{array}{l}0.227 \pm \\
0.009^{\mathrm{a}}\end{array}$ \\
\hline HF/HFr & $\begin{array}{l}4.86 \pm \\
0.066^{\mathrm{d}}\end{array}$ & $\begin{array}{l}4.85 \pm \\
0.04^{\mathrm{c}}\end{array}$ & $\begin{array}{c}4.7 \pm \\
0.126^{\mathrm{cd}}\end{array}$ & $\begin{array}{l}1.14 \pm \\
0.013^{\mathrm{a}}\end{array}$ & $\begin{array}{l}0.465 \pm \\
0.014^{c}\end{array}$ \\
\hline $\begin{array}{c}\text { HF/HFr + } \\
\text { Chamomile } \\
\text { powder }\end{array}$ & $\begin{array}{l}.05 \pm \\
0.11^{\mathrm{ab}}\end{array}$ & $\begin{array}{l}3.81 \pm \\
0.47^{\mathrm{ab}}\end{array}$ & $\begin{array}{l}3.30 \pm \\
0.05^{\mathrm{ab}}\end{array}$ & $\begin{array}{l}1.54 \pm \\
0.02^{\mathrm{cb}}\end{array}$ & $\begin{array}{c}0.286 \pm \\
0.01^{\mathrm{ab}}\end{array}$ \\
\hline $\begin{array}{c}\text { HF/HFr + } \\
\text { Chamomile } \\
\text { oil }\end{array}$ & $\begin{array}{c}3.55 \pm \\
0.131^{\text {bc }}\end{array}$ & $\begin{array}{c}4.2 \pm \\
0.044^{\mathrm{bc}}\end{array}$ & $\begin{array}{l}3.46 \pm \\
0.07^{\mathrm{ab}}\end{array}$ & $\begin{array}{l}1.68 \pm \\
0.06^{\mathrm{c}}\end{array}$ & $\begin{array}{l}0.277 \pm \\
0.006^{\mathrm{ab}}\end{array}$ \\
\hline
\end{tabular}

The values are expressed as mean $\pm S E M(n=6$ rats/ group).

Values with the same letters indicate insignificant difference and vice versa. 


\section{التأثنيرات الخافضة لمسحوق و زيث أز هار البابونج على سكر و دهون الام فى الفئران المغذاه على حمبة رهم عالية في الدهون والفركثوز لبنى احمد محمد شلباية اله ولية \\ قسم الاقتصاد المنزلي - كلية التربية النوعية -جامعة المنصورة الملخص العربي الافئي}

يهذف هذا البحث الى دراسة تأثبرات مسحوق ازهار و زيت البابونج على مستوي العي

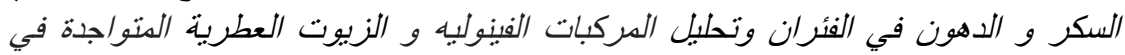

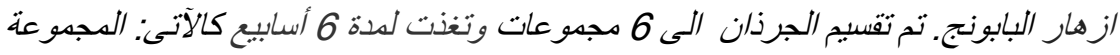

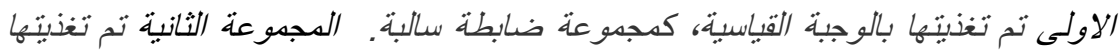

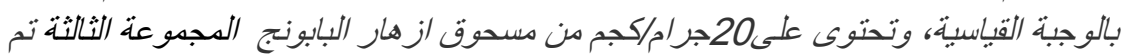

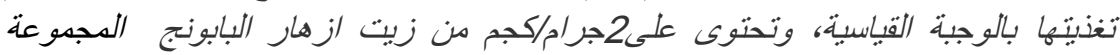

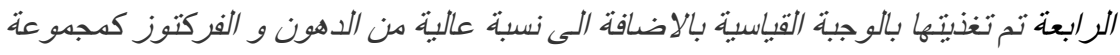

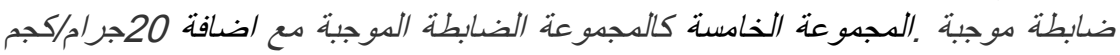

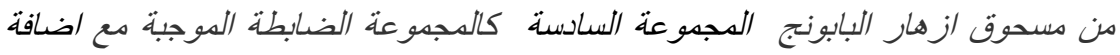

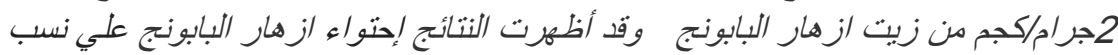

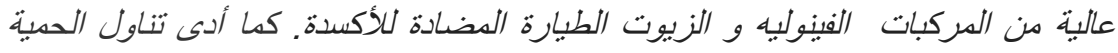

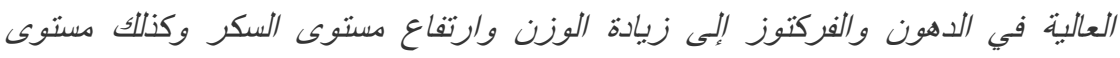

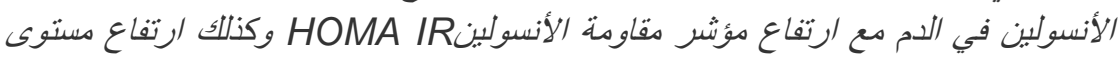

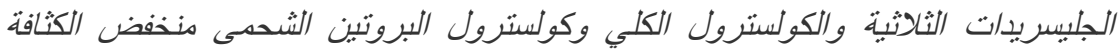

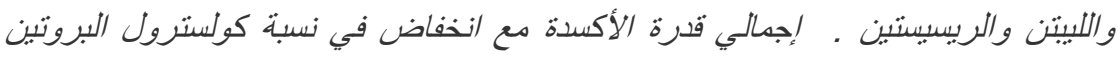

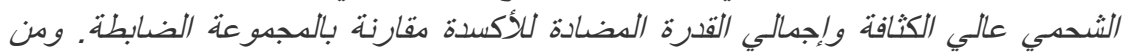

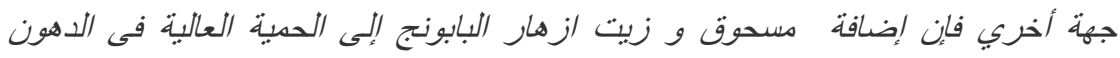

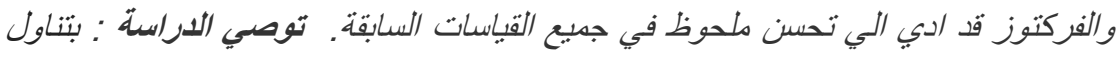

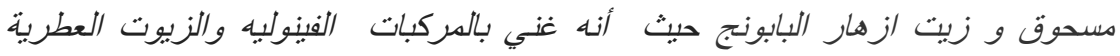

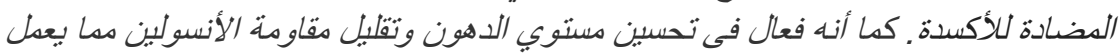

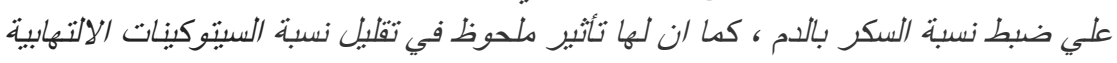

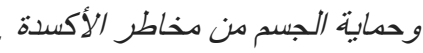

الكلمات المفتاحية: خغض السكر - الكامومبل - خفض الدهون - الالتهابات 